\title{
PERBANDINGAN HASIL BELAJAR MELALUI PENERAPAN MODEL PEMBELAJARAN THINK PAIR SHARE DENGAN MODEL PEMBELAJARAN TEAMS GAMES TURNAMENT PADA TEMA PERISTIWA DALAM KEHIDUPAN DI KELAS V SD NEGERI NO. 064025 KECAMATAN MEDAN TUNTUNGAN TAHUN PEMBELAJARAN 2018/2019
}

\section{HENY ROSA PURBA \\ (PGSD FKIP UNIVERSITAS KATOLIK SANTO THOMAS)}

\begin{abstract}
This research aims to find out the comparison application of learning model Think Pair Sharewith Teams Games Turnamento study result of $5^{\text {th }}$ grade students learning 1 and 5 of SD Negeri 064025, Medan Tuntungan subdistrict academic year 2018/2019 on. The types of research is experimental research with true experimental design method (Prates-Postes Control Group Design). The approach of research was quantitave. The population used in this study were 117 students of Elementary School 064025 in Medan Tuntungan Subdistrict. The research sample were the $60^{\text {th }}$ students fifth grade A - B classes. The sampling technique in research is cluster sample. Data collection techniques using tests namely pre-test and post-test. Tests are used to obtain student learning outcomes data. The analysis techniq ue used is by using Microsoft Exel and Statistic Program For Social Science (SPSS) ver. 21.0. The result showed that there was comparised about result study from application Think Pair Share with Teams Games Turnamen model. The results of the calculation of data analysis showed that the increase in the average value of the pre-post test results in the experimental group I through the application of the Think Pair Share Model was 16.63. While the increase in the average value of the pre-post test results in the experimental group II amounted to 11.86 . The difference in the average value of the experimental group II experimental group is only 4.77. Through the acquisition of $t_{\text {count }}(4.224)>t_{\text {table }}(1,671), H_{0}$ is rejected. This proves that there was a comparison of learning outcomes through of Think Pair Share Model with Teams Games Turnamen model the application.
\end{abstract}

Key Words : Learning Outcomes, Think Pair Share learning model, Teams Games Turnament learning model, and The Theme Of Events In Life

\section{PENDAHULUAN}

\section{Latar Belakang Masalah}

Pendidikan merupakan salah satu bagian yang saat diperhatikan oleh pemerintah di Indonesia. Mutu pendidikan di Indonesia menunjukkan kualitas sumber daya manusia yang ada di dalamnya pula. Pendidikan sangat penting bagi perkembangan karakter dan kemampuan berpikir manusia. Pendidikan yang baik 
menjadikan manusia memiliki kepribadian yang baik. Manusia yang memiliki kepribadian baik inilah yang akan mampu mengubah keadaan suatu bangsa menjadi lebih baik.

Berdasarkan Undang-undang Sistem Pendidikan Nasional Republik Indonesia No. 20 tahun 2003 Bab 1 Pasal 1 (ayat 1) bahwa pendidikan adalah usaha sadar dan terencana untuk mewujudkan suasana belajar dan proses pembelajaran agar siswa secara aktif mengembangkan potensi dirinya untuk memiliki kekuatan spiritual keagamaan, pengendalian diri, kepribadian, kecerdasan, akhlak mulia, serta keterampilan yang diperlukan dirinya, masyarakat, bangsa dan negara.

Undang- undang di atas menjelaskan bahwa pendidikan merupakan suatu usaha sadar yang dilakukan setiap orang guna untuk mengembangkan kemampuan yang ada di dalam dirinya melalui proses pembelajaran yang diterimanya. Agar memiliki keterampilan yang dapat dipergunakan bagi kepentingan banyak orang dan diri sendiri.

Sekolah merupakan salah satu wadah dimana peserta didik mendapatkan ilmu pengetahuan secara formal. Sekolah bukan hanya tempat menimba ilmu, tetapi juga sebagai tempat berkumpul, bermain, dan sebagai sarana berkomunikasi dengan masyarakat sekolah sehingga terjadi interaksi timbal balik yang dapat membantu perkembangan psikologi anak dan membentuk karakter anak didik melalui pengalaman- pengalaman yang dialaminya. Sekolah juga tempat dimana kegiatan belajar mengajar berlangsung dan tempat terjadinya interaksi antara guru dan siswa.

Sekarang ini pemerintah menetapkan bahwa setiap sekolah pada jenjang sekolah dasar wajib menggunakan kurikulum 2013. Dalam Kamus Besar Bahasa Indonesia, kurikulum merupakan perangkat mata pelajaran yang diajarkan pada lembaga pendidikan. Kurikulum 2013 didesain dan dikemas dengan melihat perkembangan jaman dan perkembangan psikologi anak didik dengan memiliki empat aspek penilaian, yaitu aspek pengetahuan, aspek keterampilan, aspek sikap, dan perilaku. 
Pengajaran pada Kurikulum 2013 bersifat tematik mempunyai beberapa tema dan subtema. Tema yang akan diteliti oleh peneliti adalah peristiwa dalam kehidupan. Namun, peneliti membatasi subtema yang akan diteliti yaitu subtema 2 peristiwa kebangsaan seputar proklamasi kemerdekaan. Dalam proses pembelajarannya, guru harus mampu mengunakan berbagai macam variasi model sesuai dengan materi yang akan diajarkan.

Model- model yang digunakan adalah model yang melibatkan siswa secara aktif dengan siswa lainnya supaya pembelajaran memberikan pengalaman langsung bagi kehidupan setiap anak didik. Pengalaman belajar secara kooperatif akan menghasilkan keyakinan yang lebih kuat bahwa seseorang merasa disukai, diterima oleh siswa lain, dan menaruh perhatian tentang bagaimana temannya belajar dan adanya keinginan untuk membantu temannya belajar. Siswa sebagai subyek yang belajar merupakan sumber belajar bagi siswa lainnya yang dapat diwujudkan dalam berbagai bentuk kegiatan misalnya diskusi, atau bekerja sama dalam melatih keterampilan-keterampilan tertentu.

Pada dasarnya kegiatan pembelajaran dilakukan agar siswa memiliki hasil belajar yang baik. Namun kenyataannya, seringkali terlihat bahwa pembelajaran kurang mampu meningkatkan hasil belajar siswa karena pembelajaran yang masih berpusat kepada guru, akibatnya siswa kurang tertarik belajar secara sungguh- sungguh. Kualitas pembelajaran yang baik dapat dilihat dari keberhasilannya dalam proses kegiatan belajar mengajar. Keberhasilan tersebut sangat ditentukan oleh model pembelajaran yang digunakan. Hal itu dikarenakan model pembelajaran merupakan suatu kerangka konseptual yang di dalamnya memuat prosedur sistematis dalam mengorganisasikan pengalaman belajar untuk mencapai tujuan belajar.

Oleh karena itu, pemilihan model pembelajaran yang tepat akan mendukung proses pembelajaran yang berjalan efisien dan efektif, serta dapat mencapai tujuan pembelajaran dengan tepat. Pada kenyataannya, kualitas pembelajaran yang banyak ditemui saat ini masih belum maksimal. Hal itu ditandai dengan proses pembelajaran yang tidak berjalan secara efektif dan tujuan pembelajaran yang belum tercapai secara maksimal. Pemilihan model 
pembelajaran yang kurang sesuai dengan karakteristik bidang studi mengakibatkan proses pembelajaran menjadi kurang, sehingga berdampak pada hasil belajar siswa yang belum optimal ditambah lagi guru- guru yang masih amatiran dalam menggunakan kurikulum 2013 berbasis tema.

Berdasarkan observasi yang dilakukan peneliti pada tema peristiwa dalam kehidupan di SD Negeri No. 064025 Kecamatan Medan Tuntungan, proses belajar mengajar yang terjadi masih bersifat konvensional. Hal itu terlihat dari guru lebih banyak berkata- kata dan berceramah di depan kelas daripada melibatkan siswa secara langsung selama proses pembelajaran. Akibatnya masih banyak siswa yang bermain- main, bercerita dengan teman sebangkunya atau tidak mau berperan aktif atau pasif selama guru menerangkan di depan.

Peneliti mengamati dua kelas yang ada di SD Negeri No. 064025 Kecamatan Medan Tuntungan, kelas V-A dan kelas V-B. Daftar nilai yang didapat berasal dari wali kelas $\mathrm{V}$-A dan kelas V-B. Untuk mengetahui tingkat ketuntasan siswa, di awal tahun ajaran berdasarkan hasil rapat guru, bahwa Kriteria Ketuntasan Minimal (KKM) di SD Negeri No. 064025 Kecamatan Medan Tuntungan adalah 70. Bahwa nilai yang diperoleh siswa kelas V-A, pada nilai < 70 terdapat 21 siswa dan nilai $\geq 70$ terdapat 10 siswa. Berdasarkan ketentuan KKM maka nilai yang berada di atas 70 dinyatakan tuntas adalah 32,3\%dan nilai yang berada dibawah 70 yaitu $67,7 \%$ Sedangkan nilai yang diperoleh siswa kelas V-B, pada nilai < 70 sebanyak 22siswa dan nilai $\geq 70$ sebanyak 8 siswa. Berdasarkan ketentuan KKM maka nilai yang berada di atas 70 dinyatakan tuntas adalah $26,7 \%$ dan nilai yang berada di bawah 70 yaitu $56,6 \%$.

Untuk memperoleh hasil belajar yang lebih baik salah satu upaya yang dapat dilakukan adalah menggunakan model pembelajaran. Menurut Fathurrohman (2015 : 30) "Model pembelajaran adalah suatu rencana yang berpijak dari teori psikologi yang digunakan sebagai pedoman bagi guru dalam merencanakan dan melaksanakan kegiatan belajar mengajar”. Dalam penelitian ini, peneliti bermaksud menggunakan model Think Pair Share dan Teams Games Turnament, model pembelajaran yang bersifat kooperatif dalam mengajar pada tema peristiwa dalam kehidupan dengan subtema 1 peristiwa kebangsaan masa 
penjajahan. Peneliti tertarik dengan kedua model ini karena sama-masa model pembelajaran bersifat kooperatif, namun jumlah anggota berbeda dan untuk mempersiapan materi pembelajaran kedua model ini memiliki perberdaan yang cukup signifikan.

Menurut Kurniasih dan Sani (2015: 58) "Model Think Pair Share menggunakan metode diskusi berpasangan yang dilanjutkan dengan diskusi pleno. Dengan model pembelajaran ini siswa dilatih bagaimana mengutarakan pendapat dan siswa juga belajar menghargai pendapat orang lain dengan tetap mengacu pada materi atau tujuan pembelajaran”. Sedangkan menurut Fathurroman (2015: 55) "Teams Games Turnament adalah salah satu model pembelajaran kooperatif yang menempatkan siswa dalam kelompok- kelompok belajar yang beranggotakan 5 sampai 6 orang siswa yang memiliki kemampuan, jenis kelamin, atau ras yang berbeda".

Kooperatif adalah suatu strategi pembelajaran yang saat ini banyak digunakan untuk mewujudkan kegiatan belajar mengajar yang berpusat pada siswa (studend oriented). Kedua model ini, yaitu model Think Pair Share dan Teams Games Tournament merupakan tipe model pembelajaran kooperatif. Model pembelajaran ini berbasis kepada proses pembelajaran siswa belajar dan bekeja sama dalam kelompok- kelompok kecil. Pembelajaran Kooperatif adalah suatu strategi pembelajaran yang saat ini banyak digunakan untuk mewujudkan kegiatan belajar mengajar yang berpusat pada siswa (studend oriented).

Pada model Think Pair Share siswa melakukan diskusi secara berpasangpasangan kemudian dilanjut dengan diskusi pleno. Tahap- tahap model ini terdiri dari tiga bagian besar yaitu Think, Pair dan Share. Pada tahap think siswa diajak berpikir mengenai materi pelajarn yang sedang dibahas, kemudian pair yaitu siswa berpasangan untuk mendiskusikan apa yang telah dia pikirkan. Setelah itu siswa akan berbagi kepada teman sekelasnya yang disebut dengan sharing. Sedangkan model Teams Games Tournament siswa dibentuk menjadi beberapa kelompok beranggotakan 5 sampai 6 siswa dan menjadikan siswa sebagai tutor sebaya bagi teman lainnya. Dalam kelompok siswa akan mengerjakan lembar kerja siswa yang sudah ada maupun yang dirancang sendiri oleh guru di kelas tersebut. Model 
pembelajaran ini mengandung unsur permainan yang bisa meningkatkan semangat belajar siswa.

Untukmengatasi masalah di atas penelitian ini mencoba menerapkan model pembelajaran kooperatif tipe Think Pair Share dan Teams Games Tournament serta melihat perbedaan hasil belajar siswa melalui penerapan model tersebut. Berdasarkan latar belakang malasah di atas, maka peneliti bermaksud melakukan penelitian dengan judul "Perbandingan Hasil Belajar Melalui Penerapan Model Pembelajaran Think Pair Share Dengan Model PembelajaranTeams Games Turnament Pada Tema Peristiwa dalam Kehidupan di Kelas V SD Negeri No. 064025 Kecamatan Medan Tuntungan Tahun Pembelajaran 2018/2019".

\section{Identifikasi Masalah}

Berdasarkan latar belakang masalah di atas, perlu diidentifikasi permasalahan yang ada, yaitu sebagai berikut.

1. Guru masih menggunakan sistem mengajar konvensional.

2. Proses pembelajaran tidak berjalan efektif.

3. Siswa belum sepenuhnya berpartisipasi aktif dalam proses pembelajaran.

4. Hasil belajar siswa masih rendah.

\section{Pembatasan Masalah}

Berdasarkan identifikasi masalah di atas, maka perlu adanya pembatasan masalah agar lebih fokus dan terarah. Batasan masalah dalam penelitian ini adalah bagaimana Perbandingan Hasil Belajar Melalui Penerapan Model PembelajaranThink Pair Share dengan Model PembelajaranTeams Games Turnament Pada Tema Peristiwa Dalam Kehidupan Pada Subtema 1 Peristiwa Kebangsaan Masa Penjajahan pada pembelajaran 1 dan 5 di Kelas V SD Negeri No. 064025 Kecamatan Medan Tuntungan Tahun Pembelajaran 2018/2019.

\section{Perumusan Masalah}

Berdasarkan batasan masalah di atas, maka masalah yang akan diteliti dapat di rumuskan sebagai berikut:

1. Bagaimana hasil belajar siswa dengan penerapan modelPembelajaranThink Pair Share pada tema peristiwa dalam kehidupan dengan subtema 1 
peristiwa kebangsaan masa penjajahan pada pembelajaran 1 dan 5 di kelas V SD Negeri No. 064025 Kecamatan Medan Tuntungan Tahun Pembelajaran 2018/2019?

2. Bagaimana hasil belajar siswa dengan penerapan modelPembelajaranTeams Games Turnament pada tema peristiwa dalam kehidupan dengan subtema 1 peristiwa kebangsaan masa penjajahan pada pembelajaran 1 dan 5 di Kelas V SD Negeri No. 064025 Kecamatan Medan Tuntungan Tahun Pembelajaran 2018/2019?

3. Apakah terdapat perbedaan Hasil Belajar Melalui Penerapan Model PembelajaranThink Pair Share dengan Model PembelajaranTeams Games Turnament pada tema peristiwa dalam kehidupan dengan subtema 1 peristiwa kebangsaan masa penjajahan pada pembelajaran 1 dan 5 di kelas V SD Negeri No. 064025 Kecamatan Medan Tuntungan Tahun Pembelajaran 2018/2019?

\section{Tujuan Penelitian}

Berdasarkan rumusan masalah di atas, tujuan yang ingin dicapai dalam penelitian ini adalah sebagai berikut :

1. Untuk mengetahui hasil belajar siswa dengan penerapan model PembelajaranThink Pair Share pada tema peristiwa dalam kehidupan dengan subtema 1 peristiwa kebangsaan masa penjajahan pada pembelajaran 1 dan 5 di kelas V SD Negeri no. 064025 kecamatan medan tuntungan tahun pembelajaran 2018/2019.

2. Untuk mengetahui hasil belajar siswa dengan penerapan model PembelajaranTeams Games Turnament pada tema peristiwa dalam kehidupan dengan subtema 1 peristiwa kebangsaan masa penjajahan pada pembelajaran 1 dan pembelajaran 5 di kelas V SD Negeri No. 064025 Kecamatan Medan Tuntungan Tahun Pembelajaran 2018/2019.

3. Untuk mengetahui Perbandingan Hasil Belajar Melalui Penerapan Model PembelajaranThink Pair Share dengan Hasil Model PembelajaranTeams Games Turnament pada tema peristiwa dalam kehidupan dengan subtema 1 peristiwa kebangsaan masa penjajahan pada pembelajaran 1 dan 5 di 
kelas V SD Negeri No. 064025 Kecamatan Medan Tuntungan Tahun Pembelajaran 2018/2019.

\section{Manfaat Penelitian}

Hasil penelitian yang diharapkan dapat memberikan manfaat kepada berbagai pihak yaitu :

1. Manfaat Teoritis

a. Hasil penelitian ini diharapkan dapat menguji ada tidaknya perbandingan hasil belajar siswa melalui penerapan model pembelajaran Think Pair Sharedengan model pembelajaran Teams Games Turnament.

b. Menambah ilmu pengetahuan dan perkembangan di dunia pendidikan serta memperkaya hasil penelitian yang sudah ada dan dapat memberi gambaran mengenai perbandingan hasil belajar siswa melalui penerapan model penbelajaran think pair sharedengan model pembelajaran Teams Games Turnament.

2. Manfaat Praktis

a. Bagi Guru

Memberikan masukan dan motivasi kepada guru- guru dalam mengunakan berbagai variasi model untuk dikembangkan saat mengajar di kelas.

b. Bagi Peneliti Berikutnya

Menambah wawasan dan pengetahuan peneliti memilih dan menggunakan model pembelajaran yang menarik sehingga siswa dapat berperan aktif dalam proses pembelajaran.

c. Bagi Sekolah

Sebagai masukan untuk meningkatkan mutu pendidikan di sekolah dengan melihat hasil belajar siswa yang meningkat melalui penerapan berbagai macam model yang diterapkan di kelas. 


\section{METODE PENELITIAN}

\section{Pendekatan dan Metode Penelitian}

Dalam penelitian, setiap peneliti sebaiknya menentukan terlebih dahulu metode/ jenis penelitian yang akan digunakan. Adapun metode penelitian yang digunakan dalam penelitian ini adalah metode kuantitatif jenis eksperimen. Menurut Sugiyono (2016: 160) "metode eksperimen adalah metode penelitian kuantitatif yang digunakan untuk mengetahui pengaruh variabel independen (treatment/ perlakuan) terhadap variabel dependen (hasil) dalam kondisi yang terkendali”. Dalam penelitian ini terdapat grup eksperimen I dan grup eksperimen II. Model pembelajaran Think Pair Share (TPS) digunakan pada grup eksperimen I dan model pembelajaranTeams Games Turnamen (TGT) digunakan pada grup eksperimen II. Kedua kelompok grup diberikan materi ajar yang sama yaitu pada tema peristiwa dalam kehidupan dengan subtema 1 peristiwa kebangsaan masa penjajahan.

\section{Tempat, Waktu, dan Kegiatan Penelitian}

\section{Tempat Penelitian}

Penelitian ini dilaksanakan di SD Negeri No. 064025 Kecamatan Medan Tuntungan pada siswa kelas V tahun pembelajaran 2018/ 2019. Adapun pemilihan tempat tersebut sebagai lokasi penelitian dikarenakan pertimbangan sebagai berikut:

1. Di sekolah tersebut belum pernah dilakukan penelitian yang sama dengan permasalahan yang akan diteliti.

2. Dari jumlah siswa di SD Negeri No. 064025 Kecamatan Medan Tuntungan cukup memadai untuk dijadikan subjek penelitian

3. Di Negeri No. 064025 Kecamatan Medan Tuntungan peneliti mendapat izin untuk meneliti.

\section{Waktu Penelitian}

Waktu pelaksanaan penelitian ini diperkirakan berlangsung pada bulan April- Mei semester dua tahun ajaran 2018/2019 yang disesuaikan dengan jadwal pelajaran di sekolah. 


\section{Rancangan/ Desain Penelitian}

Desain penelitian yang digunakan yaitu metode true experimental design. Salah satu bentuk metode true experimental design yakni pretest- posttest control group design. Menurut Sugiyono (2016: 16) "pretest- posttest control group design adalah desain yang terdiri dari dua kelompok yang dipilih secara random, kemudian diberi pretest untuk mengetahui keadaan awal adakah perbedaan antara kelompok eksperimen dan kelompok kontrol".

Adapun variabel- variabel yang digunakan dalam penelitian ini terdiri dari variabel bebas (independen) yaitu model pembelajaran Think Pair Share $\left(\mathrm{X}_{1}\right)$ dan model pembelajaran Teams Games Turnament $\left(\mathrm{X}_{2}\right)$, sedangkan variabel terikat (dependen) yaitu hasil belajar $\left(\mathrm{Y}_{1}\right)$. Kelompok eksperimen satu yaitu kelompok yang mendapat perlakuan model pembelajaran Think Pair Share dan kelompok dua yaitu kelompok yang mendapatkan perlakuan model pembelajaran Teams Games Turnament. Selanjutnya kedua kelas diberi test untuk mengetahui bagaimana perubahan hasil belajar setelah perlakuan diberikan.

Tabel 3.2 Pretes- Posttes Control Group Design

\begin{tabular}{|c|c|c|c|}
\hline Grup & Prates & Perlakuan & Postes \\
\hline $\mathrm{E}_{1}$ & $\mathrm{O}_{1}$ & $\mathrm{X}_{1}$ & $\mathrm{O}_{2}$ \\
\hline $\mathrm{E}_{2}$ & $\mathrm{O}_{3}$ & $\mathrm{X}_{2}$ & $\mathrm{O}_{4}$ \\
\hline
\end{tabular}

Keterangan

$\mathrm{E}_{1}=$ Kelompok 1 (kelas eksperimen 1)

$\mathrm{E}_{2}=$ kelompok 2 (kelas eksperimen 2)

$\mathrm{O}_{1}=$ Pretest kelompok eksperimen 1

$\mathrm{O}_{2}=$ Posttest kelompok eksperimen 1

$\mathrm{X}_{1}=$ Penerapan Model Think Pair Share

$\mathrm{X}_{2}=$ Penerapan Model Teams Games Turnament

$\mathrm{O}_{3}=$ Pretest kelompok eksperimen 2

$\mathrm{O}_{4}=$ posttest kelompok eksperimen 2

\section{Populasi dan Sampel Penelitian}

\section{Populasi}

Menurut Arikunto (2014: 173) "populasi adalah keseluruhan subjek penelitian. Apabila seseorang ingin meneliti semua elemen yang ada dalam 
wilayah penelitian, maka penelitiannya merupakan penelitian populasi, studi atau penelitiannya juga disebut studi populasi atau studi kasus. Selain itu, Sugiyono (2016: 62) mengatakan "Populasi adalah wilayah generalisasi yang terdiri atas: objek/ subjek yang mempunyai kuantitas dan karakteristik tertentu yang ditetapkan oleh peneliti untuk dipelajari dan kemudian ditarik kesimpulannya". Artinya populasi tidak hanya kepada manusia, tetapi juga objek atau benda- benda lainnya yang memiliki sifat/ karakter yang sama.

Berdasarkan pendapat di atas, maka yang menjadi populasi dalam penelitian ini adalah seluruh siswa kelas V SD Negeri No. 064025 Kecamatan Medan Tuntungan Tahun Pembelajaran 2018/2019 yang berjumlah sebanyak 117 siswa.

Jumlah Siswa Kelas V SD Negeri No. 064025 Kecamatan Medan

Tuntungan Tahun Pembelajaran 2018/2019

\begin{tabular}{|c|c|c|}
\hline No & Kelas & Jumlah siswa \\
\hline 1 & V-A & 29 \\
\hline 2 & V-B & 31 \\
\hline 3 & $\mathrm{~V}-\mathrm{C}$ & 29 \\
\hline 4 & V-D & 28 \\
\hline & glah & 117 \\
\hline
\end{tabular}

Sumber: Tata Usaha SDN 064025 Kecamatan Medan Tuntungan T.P 2018/2019

\section{Sampel}

Sampel merupakan sebagian dari jumlah yang dimiliki populasi dengan karakteristik sama. Menurut (Sugiyono, 2017: 81) sampel adalah bagian dari jumlah dan karakteristik yang dimiliki oleh populasi tersebut. Bila populasi besar, dan peneliti tidak mungkin mempelajari semua yang ada pada populasi, misalnya karena keterbatasan dana, tenaga, dan waktu, maka peneliti dapat menggunakan sampel yang diambil dari populasi itu. Artinya adalah sebagian atau jumlah yang mewakili dari popusai yang dijadikan sebagai objek penelitian.

Teknik pengambilan data dapat dilakukan dengan beberapa cara. Menurut Hadi (2015: 116), dalam sampel klaster, satuan- satuan sampel tidak terdiri dari individu- individu, melainkan dari kelompok- kelompok individu atau klaster. Maka dalam penelitian ini, peneliti menggunakan teknik sampel klaster karena populasi yang ada sudah dikelompokkan dalam bentuk kelas- kelas. Peneliti akan menjadikan dua kelas sebagai sampel, yaitu kelas V-A sebagai grup 
eksperimen I dengan model pembelajaran Think Pair Share dan kelas V-B sebagai grup eksperimen II dengan modelpembelajaranTeams Games Turnament. Sehingga sampel berjumlah sebanyak 60 orang siswa yang berasal dari kelas V-A (29 orang) dan kelas V-B (31 orang). Untuk lebih jelas dapat dilihat pada tabel di bawah ini.

Sampel Penelitian

\begin{tabular}{|c|c|c|}
\hline No & Kelas & Jumlah siswa \\
\hline 1 & $\mathrm{~V}-\mathrm{A}$ & 29 \\
\hline 2 & V-B & 31 \\
\hline \multicolumn{2}{|c|}{ Jumlah } & 60 \\
\hline
\end{tabular}

\section{Jenis dan Sumber Data}

\section{Jenis data}

Data adalah hasil pencatatan penelitian, baik yang berupa fakta maupun angka. Menurut Sugiyono (2017: 308) "pengumpulan data dapat menggunakan sumber primer dan sumber skunder. Sumber primer adalah sumber data yang langsung memberikan data kepada pengumpul data, dan sumber skunder merupakan sumber yang tidak langsung memberikan data kepada pengumpul data". Maka peneliti akan mengunakan sumber data yaitu data primer yang di dapat langsung dari subjek penelitian.

\section{Sumber data}

Menurut Arikunto (2014: 172) "bahwa sumber data penelitian adalah subyek dari mana data dapat diperoleh". Maka dalam peneltian ini, sumber data yang digunakan adalah 60 orang siswa kelas V dari 117 orang populasi.

\section{Teknik dan Alat Pengumpulan Data}

\section{Observasi}

Menurut Sudjana (2016: 84) "observasi atau pengamatan sebagai alat penilaian banyak digunakan untuk mengukur tingkah laku individu ataupun proses terjadinya suatu kegiatan yang diamati, baik dalam situasi yang sebenarnya maupun dalam situasi buatan". Dalam penelitian ini, peneliti melakukan observasi langsung terhadap kegiatan belajar mengajar yang dilakukan guru di dalam kelas di saat mengajar. Observasi ini dilakukan berguna untuk mengetahui kondisi belajar di kelas yang dilakukan oleh guru saat kegiatan pembelajaran. 
Tes

Untuk medapatkan data, peneliti juga menggunakan tes sebagai alat pengumpulan data. Mardapi (Sugiyono, 2016: 193) mendefinisikan bahwa "tes merupakan sejumlah pernyataan yang harus ditanggapi dengan tujuan mengukur tingkat kemampuan seseorang atau mengungkap aspek tertentu dari orang yang dikenai tes". Dalam penelitian ini, penetili akan menggunakan multiple choice test atau tes pilihan berganda.

Menurut Arikunto (2016: 183) "multiple choice test terdiri atas suatu keterangan atau pemberitahuan tentang suatu pengertian yang belum lengkap. Dan untuk melengkapinya harus memilih satu dari beberapa kemungkinan jawaban yang telah disediakan". Penyusunan instrumen ini mengacu pada ranah kognitif taksonomi Bloom yang sudah direvisi yaitu mulai dari C1 - C4. Ranah kognitif $\mathrm{C} 1$ adalah mengingat, $\mathrm{C} 2$ adalah memahami, $\mathrm{C} 3$ adalah mengaplikasikan, dan $\mathrm{C} 4$ adalah menganalisis.

\section{Uji Instrumen Penelitian}

Sebelum tes diberikan kepada sampel maka soal diuji terlebih dahulu. Tes ini diuji cobakan kepada siswa lain yang dinilai memiliki kemampuan yang sama dengan siswa yang akan diteliti. Butiran soal yang sudah diuji cobakan tersebut akan diuji cobakan ke sekolah. Untuk melihat karakteristik tes tersebut dilakukan uji validitas dan reliabilitas tes serta menggunakan aplikasi SPSS ver. 21.0

\section{Uji Validitas}

Menurut Arikonto (2014: 211) "validitas adalah suatu ukuran yang menunujukkan tingkat- tingkat kevalidan atau sesahihan suatu instrument. Suatu instrument yang valid atau sahih mempunyai validitas tinggi”.

$$
\mathrm{Rxy}=\frac{N \Sigma x y-(\Sigma x)(\Sigma y)}{\sqrt{\left(N \Sigma X^{2}-\Sigma X\right)^{2}\left(N \Sigma Y^{2}-\Sigma Y\right)^{2}}} \quad \text { (Arikunto, 2014: 231) }
$$

Keterangan :

$$
\begin{array}{ll}
\text { Rxy } & \text { = Koefisien korelasi } \mathrm{x} \text { dan } \mathrm{y} \\
\mathrm{N} & \text { = Jumlah responden / banyak siswa peserta tes } \\
\mathrm{X} & \text { = Jumlah skor diperoleh siswa untuk tiap item soal } \\
\mathrm{Y} & \text { = Jumlah skor total yang benar }
\end{array}
$$


Dari hasil perhitungan uji validitas instrumen soal dengan menggunakan program SPSS ver 21.0 pada tabel 3.6 maka diperoleh soal yang valid sebanyak 34 butir soal dari 60 butir soal, sesuai dengan hasil perhitungan diperoleh $r_{\text {hitung }}>$ $r_{\text {tabel }}$ dengan taraf signifikan $5 \%$.

Dari 34 soal yang valid, maka semua soal digunakan sebagai soal prates dan soal postes. Penilaiannya dilakukan dengan cara jumlah jawaban benar dikalikan 100 (seratus) dibagi 34 (tiga puluh empat). Apabila siswa dapat mengerjakan keseluruhan soal dengan benar maka akan mendapat nilai 100.

\section{Uji Reliabilitas}

Reliabilitas menunjuk pada satu pengertian bahwa sesuatu instrument cukup dapat dipercaya untuk digunakan sebagai alat mengumpulkan data karena instrument tersebut sudah baik (Arikunto, 2014: 221). Untuk menguji reliabilitas tes dalam penelitian digunakan rumus KR-20 sebgai berikut :

$$
\mathrm{R} 11=\left(\frac{n}{n-1}\right)\left(\frac{s^{2}-\Sigma p q}{s^{2}}\right)
$$

\section{Keterangan :}

$$
\begin{array}{ll}
\mathrm{R} 11 & =\text { Reliabilitas tes } \\
\mathrm{p} & =\text { Proporsi subjek yang menjawab item dengan benar } \\
\mathrm{q} & =\text { Proporsi subjek yang menjawab item dengan salah } \\
\Sigma \mathrm{pq} & =\text { Jumlah hasil perkalian antara } \mathrm{p} \text { dan } \mathrm{q} \\
\mathrm{n} & =\text { Banyak nya item } \\
\mathrm{S} & \quad=\text { Standar deviasi }
\end{array}
$$

Rumus untuk mencari standar deviasi sebagai berikut :

$$
\mathrm{SD}=\sqrt{\frac{\Sigma f x^{2}}{N}}
$$

Keterangan :

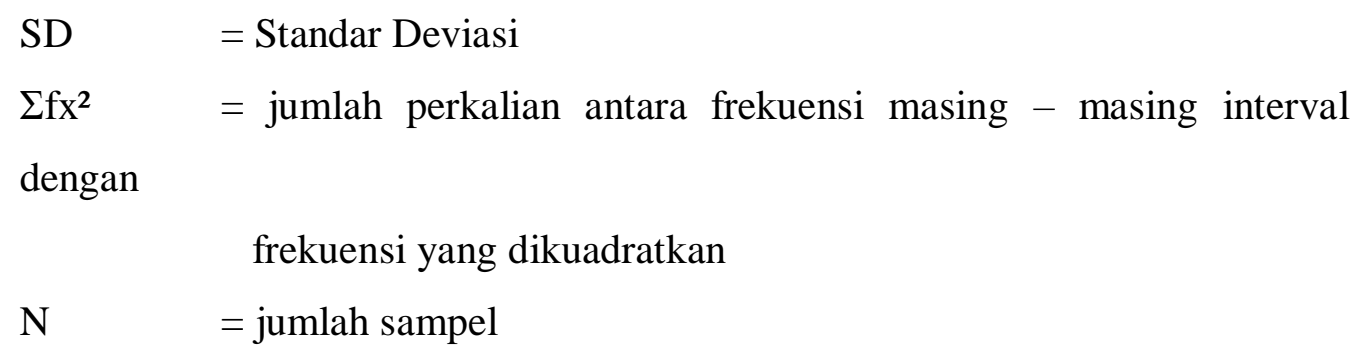


Interpretasi nilai $\mathrm{r}_{11}$ mengacu pada Jihad dan Haris (2012: 180) dipaparkan pada tabel 3.7.

Tabel 3.7 Kualifikasi Koefisien Korelasi

\begin{tabular}{|c|l|l|}
\hline No & \multicolumn{1}{|c|}{ Koefisien Korelasi } & \multicolumn{1}{c|}{ Kualifikasi } \\
\hline 1 & $0,80<\mathrm{r}_{\mathrm{xy}} \leq 1,00$ & Sangat tinggi \\
\hline 2 & $0,60<\mathrm{r}_{\mathrm{xy}} \leq 0,80$ & Tinggi \\
\hline 3 & $0,40<\mathrm{r}_{\mathrm{xy}} \leq 0,60$ & Cukup \\
\hline 4 & $0,20<\mathrm{r}_{\mathrm{xy}} \leq 0,40$ & Rendah \\
\hline 5 & $\mathrm{r}_{\mathrm{xy}} \leq 0,40$ & Sangat rendah \\
\hline
\end{tabular}

Tehnik Pengolahan (Analisis) Data

Penelitian ini dilakukan dengan bantuan program SPSS ver.21.0 dan Ms. Exel 2007. Langkah- langkah uji prasyarat analisis dan analisis data dilakukan sebagai berikut :

\section{Uji Normalitas}

Menurut Sumanto (2014: 146) "Uji normalitas data dimaksudkan untuk memastikan bahwa data sampel berasal dari populasi yamg berdistribusi normal". Untuk mengetahui data berdistribusi normal atau tidak, peneliti menggunakan analisa Kolmogrov-Smirnov dengan bantuan program SPSS ver. 21.0.Kriteria normal dipenuhi jika hasil uji tidak signifikan untuk suatu taraf signifikansi ( $\alpha=$ $0,05)$ tertentu.

Jika signifikansi yang diperoleh $>\alpha$, maka sampel yang berasal dari populasi yang berdistribusi normal. $\mathrm{H}_{0}$ ditolak. Itu berarti data berdistribusi normal.

Jika signifikansi yang diperoleh $<\alpha$, maka sampe bukan berasal dari populasi yang berdistribusi normal. $\mathrm{H}_{0}$ diterima. Itu berarti data tidak berdistribusi normal.

\section{Uji Homogenitas}

Menurut Sumanto (2014: 149) "uji homogenitas dimaksudkan untuk memperlihatkan bahwa kelompok atau lebih data sampel berasal dari populasi yang memiliki variansi yang sama". Dalam penelitian ini, uji homogenitas dilakukan pada uji perbedaan yang akan menggunakan bantuan program SPSS ver.21.0.

Interpretasi dilakukan dengan berdasarkan ketetapan taraf signifikansi $(\alpha=0,05)$.

Jika signifikansi yang diperoleh $>\alpha$ maka variansi setiap sampel adalah homogen.

Jika signifikansi yang diperoleh $<\alpha$ maka variansi setiap sampel tidak homogen. 


\section{Uji Hipotesis}

Uji hipotesis dilakukan dengan cara analisis uji-t. "uji-t digunakan untuk menentukan apakah dua mean berbeda secara signifikan atau tidak pada tingkat probabilitas yang dipilih" (Sumanto, 2014: 69). Perhitungan dilakukan dengan bantuan program SPSS ver. 21.0. dengan ketentuan jika harga t-tihung sama dengan atau lebih besar dengan harga t-tabel, peneliti menolak hipotesis nol, mean-mean berbeda secara signifikan pada tinggat yang dipilih (Sumanto, 2014:70).

\section{Prosedur Penelitian}

Prosedur penelitian adalah tahap- tahap kegiatan yang akan dilaksanakan dengan mempersiapkan materi pembelajaran serta pengumpulan data. Dilakukan dengan langkah-langkah sebagai berikut:

1. Penelitian Pendahuluan

a. Peneliti membuat surat izin penelitian pendahuluan ke sekolah.

b. Menentukan grup eksperimen I dan grup eksperimen II.

2. Tahap Perencanaan

a. Peneliti membuat proposal dan melakukan seminar proposal.

b. Menyusun Rencana Pelaksanaan Pembelajaran (RPP) dengan ModelpembelajaranThink pair share dan modelpembelajaranTeams Games Turnament.

3. Tahap Pelaksanaan Penelitian

a. Menyiapkan instrumen penelitian.

b. Melakukan uji coba instrumen penelitian kepada subjek yang memiliki karakteristik yang sama dengan sampel yang akan diteliti.

c. Melakukan uji instrumen dengan melihat validitas dan reliabilitas instrumen.

d. Memberikan tes awal pada grup eksperimen I dan grup eksperimen II (prates).

e. Melaksanakan penelitian/ perlakuan dengan cara mengajar di kelas menggunakan modelpembelajaranThink Pair Share dan modelpembelajaranTeams Games Turnament. 
f. Memberikan tes akhir pada grup eksperimen I dan grup eksperimen II (postes).

4. Tahap akhir

a. Memeriksa hasil belajar siswa.

b. Melakukan analisis terhadap hasil belajar antara pre-test dengan posttest.

c. Menarik kesimpulan dari hasil penelitian yang telah dilakukan.

\section{HASIL PENELITIAN DAN PEMBAHASAN}

\section{Pembahasan Hasil Temuan}

Seperti yang sudah dirumuskan dalam Bab 1, penelitian ini fokus pada pertanyaan-pertanyaan sebagai berikut:

1. Bagaimana hasil belajar siswa dengan penerapan model pembelajaranThink Pair Share pada tema peristiwa dalam kehidupan dengan subtema 1 peristiwa kebangsaan masa penjajahan pada pembelajaran 1 dan 5 di kelas V SD Negeri No. 064025 Kecamatan Medan Tuntungan Tahun Pembelajaran 2018/2019?

2. Bagaimana hasil belajar siswa dengan penerapan modelpembelajaranTeams Games Turnament pada tema peristiwa dalam kehidupan dengan subtema 1 peristiwa kebangsaan masa penjajahan pada pembelajaran 1 dan 5 di Kelas V SD Negeri No. 064025 Kecamatan Medan Tuntungan Tahun Pembelajaran 2018/2019?

3. Apakah terdapat perbandingan Hasil Belajar Melalui Penerapan Model pembelajaranThink Pair Share dengan Model pembelajaranTeams Games Turnament pada tema peristiwa dalam kehidupan dengan subtema 1 peristiwa kebangsaan masa penjajahan di kelas V SD Negeri No. 064025 Kecamatan Medan Tuntungan Tahun Pembelajaran 2018/2019?

Berikut ini akan diuraikan satu persatu pertanyaan-pertanyaan penelitian tersebut berdasarkan hasil analisa data penelitian: 


\section{Hasil belajar pada Pembelajaran 1 dan Pembelajaran 5 dengan menerapkan} Model Pembelajaran Think Pair Share pada siswa kelas V SD Negeri 064025

\section{Medan Tuntungan Tahun Pembelajaran 2018/2019}

Hasil belajar adalah hasil evaluasi siswa dalam bentuk nilai yang menyangkut pengetahuan (kognitif) yang diperoleh dari proses belajar. Nilai hasil belajar dalam penelitian ini ada dua jenis, yaitu nilai prates dan nilai postes. Nilai prates merupakan nilai hasil belajar sebelum diberikan perlakuan dengan penerapan Model pembelajaran Think Pair Share. Nilai postes merupakan nilai hasil belajar sesudah perlakuan yaitu dengan penerapan Model pembelajaranThink Pair Share.

Berdasarkan hasil penelitian diperoleh nilai minimum prates yaitu 26,47 dan nilai maksimun yaitu 88,24. Hasil perhitungan dari hasil belajar siswa didapatkan nilai rata-rata (mean) prates sebesar 58,21. Sedangkan nilai minimum postes adalah 38,24 dan nilai maksimun yaitu 97,06. Hasil perhitungan dari hasil belajar siswa didapatkan nilai rata-rata (mean) postes sebesar 74,44.

Nilai Kriteria Ketuntasan Minimum (KKM) yang berlaku di SD Negeri 064025 Medan Tuntungan pada tema peristiwa dalam kehidupan adalah 70 . Berdasarkan perolehan hasil nilai rata-rata prates dan postes dapat dikatakan bahwa nilai hasil belajar dengan menerapkan Model pembelajaranThink Pair Share pada siswa kelas V SD Negeri 064025 termasuk baik karena sudah di atas nilai KKM. Kegiatan pembelajaran sebelum dan sesudah perlakuan dengan penerapan Model pembelajaranThink Pair Share memiliki pengaruh pada hasil belajar siswa. Hal ini terbukti dari peningkatan nilai rata-rata. Peningkatan nilai rata-rata tersebut sebesar 16,23.

Peningkatan ini menunjukkan bahwa penerapan Model pembelajaranThink Pair Share membuat siswa lebih giat mengikuti proses belajar pada tema peristiwa dalam kehidupan dengan subtema 1 Peristiwa Kebangsaan Masa Penjajahan. Hal ini disebabkan karena Model pembelajaranThink Pair Share menekankan pembelajaran berpikir terlebih dahulu kemudian berpasangan dengan teman sebangku mendiskusikan materi pembelajaran, dan berbagi kepada teman sekelas. Dengan demikian semakin banyak ide yang disampaikan oleh 
pasangan kelompok maka semakin banyak yang diketahui oleh siswa lainnya. Peningkatan nilai rata-rata sebesar 16,63 merupakan peningkatan yang cukup besar.

\section{Hasil belajar pada Pembelajaran 1 dan 5 dengan menerapkan Model Pembelajaran Teams Games Turnament pada siswa kelas V SD Negeri 064025 Medan Tuntungan Tahun Pembelajaran 2018/2019}

Hasil belajar adalah hasil evaluasi siswa dalam bentuk nilai yang menyangkut pengetahuan (kognitif) yang diperoleh dari proses belajar. Nilai hasil belajar dalam penelitian ini ada dua jenis, yaitu nilai prates dan nilai postes. Nilai prates merupakan nilai hasil belajar sebelum diberikan perlakuan dengan penerapan Teams Games Turnament. Nilai postes merupakan nilai hasil belajar sesudah perlakuan yaitu dengan penerapan Model pembelajaranTeams Games Turnament. Berdasarkan hasil penelitian diperoleh nilai minimum prates siswa yaitu 23,53 dan nilai maksimun prates siswa yaitu 94,12. Hasil perhitungan dari hasil belajar siswa didapatkan nilai rata-rata (mean) prates sebesar 54,65. Nilai minimum postes siswa dengan penerapan modelpembelajaranTeams Games Turnament yaitu 32,35 dan nilai maksimum postes siswa adalah 100. Hasil perhitungan dari hasil belajar siswa didapatkan nilai rata-rata (mean) postes sebesar 66,51.

Nilai Kriteria Ketuntasan Minimum (KKM) yang berlaku di SD Negeri 064025 Kecamatan Medan Tuntungan pada tema peristiwa dalam kehidupan adalah 70. Berdasarkan perolehan hasil nilai rata-rata prates dan postes dapat dikatakan bahwa nilai hasil belajar siswa kelas V SD Negeri 064025, sebelum dan sesudah perlakuan dengan penerapan Model Teams Games Turnament memiliki pengaruh. Hal ini terbukti dari peningkatan nilai rata-rata sebesar 11,86.

Peningkatan ini menunjukkan bahwa penerapan Model Pembelajaran Teams Games Turnament membuat siswa lebih termotivasi dalam mengikuti proses belajar pada tema peristiwa dalam kehidupan dengan subtema 1 peristiwa kebangsaan masa penjajahan. Namun, peningkatan nilai rata- rata tidak sebesar peningkatan nilai rata- rata pada penerapan model pembelajaran Think Pair share. Hal ini disebabkan karena Model Pembelajaran Teams Games Turnament 
terdapat kesulitan dalam pembagian kelompok belajar, siswa yang memiliki kemampuan tinggi ke setiap kelompok tidak merata. Siswa juga lebih terfokus kepada games yang dilakukan pada saat pembelajaran sedangkan pada saat diberikan tes, tidak semua siswa dapat dengan fokus mengerjakan. Peningkatan nilai rata-rata sebesar 11,86 merupakan peningkatan yang tidak terlalu besar.

\section{Perbandingan Hasil Belajar Pembelajaran 1 dan 5 dengan menerapkan} Model Pembelajaran Think Pair Share dengan Model Pembelajaran Teams Games Turnamen pada siswa kelas V SD Negeri 064025 Medan Tuntungan Tahun Pembelajaran 2018/2019

Sesuai dengan hasil penelitian bahwa hasil belajar pada tema peristiwa dalam kehidupan dengan subtema 1 peristiwa kebangsaan masa penjajahan pada pembelajaran 1 dan 5 dengan menerapkan Model pembelajaranThink Pair Share pada siswa kelas V SD Negeri 064025 Kecamatan Medan Tuntungan termasuk baik karena nilai rata- rata sudah di atas nilai Kriteria Ketuntasan Minimum (KKM), begitu juga dengan menerapkan model pembelajaran Teams Games Turnament, nilai rata-rata hasil belajar siswa kelas V SD Negeri 064025 Kecamatan Medan Tuntungan sebelum dan sesudah penerapan model pembelajaran Teams Games Turnament mengalami peningkatan namun, rata- rata tersebut tidak mencapai nilai KKM.

Hasil penelitian menunjukkan bahwa penerapan Model Pembelajaran Think Pair Share pada grup eksperimen I mengalami peningkatan nilai rata-rata prates dan nilai postes sebesar 16,63. Hasil nilai rata-rata prates dan postes penerapan Model Pembelajaran Teams Games Turnament pada grup eksperimen II mengalami peningkatan sebesar 11,86. Perbandingan nilai rata-rata hasil belajar siswa dengan penerapan Model Pembelajaran Think Pair Share dengan penerapan Model Pembelajaran Teams Games Turnament pada siswa kelas V SD Negeri 064025 Kecamatan Medan Tuntungan sebesar 4,77. Hal ini menunjukkan bahwa hasil belajar siswa terdapat perbedaan yang diajarkan pada grup eksperimen I melalui penerapan Model pembelajaranThink Pair Share dengan grup eksperimen II melalui penerapan model pembelajaranTeams Games Turnament. 
Berikutnya, mengapa hasil pembelajaran siswa dengan penerapan Model pembelajaranThink Pair Share lebih tinggi dibandingkan dengan penerapan model pembelajaranTeams Games Turnamen. Kedua pembelajaran ini merupakan pembelajaran yang bersifat kooperatif. ModelpembelajaranThink pair Share dan model pembelajaranTeams Games Turnament sama- sama model pembelajaran dalam bentuk kelompok. Pada model pembelajaranThink Pair Share jumlah siswa dalam kelompok berjumlah 2 orang atau sering disebut berpasangan (pair). Menekankan pada aspek berpikir secara mandiri sebelum berdiskusi dengan teman sebangkunya. Kemudian berbagi dengan teman sekelas sehingga setiap siswa mendapat banyak pengetahuan yang beragam dari setiap pasangan yang menyampaikan hasil diskusinya.

Penelitian ini dikaitkan dengan hasil penelitian yang relevan. Penelitian yang dilakukan oleh Aulia (2016), menyatakan bahwa penerapan Model PembelajaranThink Pair Sharelebih tinggi dibandingkan dengan siswa yang diajar dengan penerapan model pembelajaran Teams Games Tournament. Penelitian kedua oleh Mukhadimah (2016), Hasil penelitiannya menunjukkan bahwa ada perbedaan mean yang sangat meyakinkan antara kelas dengan menggunakan model pembelajaranTeam Game Tournamentdan kelas yang menggunakan model pembelajaranThink Pair Share. Dimana nilai rata-rata kelas model pembelajaranThink Pair Share lebih tinggi daripada kelas dengan penerapan model pembelajaranTeams Games Tournament. Hasil penelitian ketiga dilakukan oleh Dianti, dkk (2016), penelitian ini menyimpulkan bahwa terdapat perbedaan yang signifikan antara hasil belajar siswa dengan menggunakan model pembelajaran Think Pair Share dengan menggunakan model pembelajaran Teams Games Turnament. Bahwa hasil belajar siswa dengan menggunakan model pembelajaran Think Pair Share lebih tinggi daripada menggunakan model pembelajaran Teams Games Turnament.

Berdasarkan penjelasan di atas dapat disimpulkan bahwa penerapan Model pembelajaranThink Pair Share memiliki pengaruh yang lebih besar terhadap hasil belajar siswa. Peningkatan yang terjadi sebesar 16,63, sedangkan pengaruh penerapan model pembelajaranTeams Games Turnament sebesar 11,86. 
Serta perbandingan hasil belajar melalui penerapan model Think Pair Share dengan penerapan model pembelajaranTeams Games Turnament sebesar 4,77.

\section{PENUTUP}

\section{Simpulan}

Berdasarkan hasil dan pembahasan penelitian tentang Perbandingan Hasil Belajar Melalui Penerapan Model pembelajaranThink Pair Share Dengan Model pembelajaranTeams Games Turnament Pada Tema Peristiwa Dalam Kehidupan Di Kelas V SD Negeri No. 064025 Kecamatan Medan Tuntungan, maka dapat disimpulkan sebagai berikut:

1. Hasil belajar siswa pada tema Peristiwa dalam Kehidupan dengan subtema 1 peristiwa kebangsaan masa penjajahan pada pembelajaran 1 dan 5 di kelas V SD Negeri No. 064025 Kecamatan Medan Tuntungan Tahun Pembelajaran 2018/2019, dengan penerapan model pembelajaranThink Pair Share yaitu nilai rata-rata prates sebesar 58,21 dan nilai rata-rata postes sebesar 74,44 mengalami peningkatan hasil belajar sebesar 16,63

2. Hasil belajar siswa pada tema Peristiwa dalam Kehidupan dengan subtema 1 peristiwa kebangsaan masa penjajahan pada pembelajaran 1 dan 5 di kelas V SD Negeri No. 064025 Kecamatan Medan Tuntungan Tahun Pembelajaran 2018/2019, dengan penerapan model pembelajaranTeams Games Turnament yaitu nilai rata-rata prates sebesar 54,65 dan nilai ratarata postes sebesar 66,51 mengalami peningkatan nilai hasil belajar sebesar 11,86

3. Hasil belajar siswa pada tema Peristiwa dalam Kehidupan dengan subtema 1 peristiwa kebangsaan masa penjajahan pada pembelajaran 1 dan 5 di kelas V SD Negeri No. 064025 Kecamatan Medan Tuntungan Tahun Pembelajaran 2018/2019, dengan penerapan model pembelajaranThink Pair Share memiliki perbedaan yang tidak terlalu besar. Penerapan Model pembelajaran Think Pair Sharelebih tinggi sebesar 4,77 dibandingkan dengan hasil belajar siswa dengan penerapan model pembelajaranTeams Games Turnament. Hal ini menunjukkan bahwa penerapan Model 
Pembelajaran Think Pair Share memberikan pengaruh yang lebih besar terhadap hasil belajar siswa jika dibandingkan dengan penerapan model pembelajaranTeams Games Turnament.

\section{Saran}

Berdasarkan simpulan, implikasi, dan keterbatasan penelitian yang sudah disampaikan, maka dapat diberikan saran-saran sebagai berikut:

1. Bagi siswa hendaknya memberi perhatian pada saat guru sedang mengajar. Tentu cara belajar yang baik dan efisien, dan hendaknya siswa dapat berperan aktif, agar proses belajar berlangsung terjadi komunikasi dua arah.

2. Bagi guru khususnya guru kelas, agar memilih model pembelajaran yang paling sesuai dengan materi pembelajaran yang diajarkan dan sebagai tuntutan kurikulum 2013 yang menuntut siswa lebih berperan aktif, maka disarankan guru menggunakan model yang bervariasi, seperti model pembelajaran Think Pair Share.

3. Bagi peneliti selanjutnya yang ingin melakukan penelitian yang sama, disarankan untuk mengembangkan penelitian ini dengan materi lainnya, untuk mengetahui pengaruh model pembelajaran Think Pair Sharuntuk meningkatkan hasil belajar siswa pada materi lainnya.

\section{DAFTAR PUSTAKA}

Abdurrahman, Mulyono. 2012. Anak Berkesulitan Belajar. Jakarta: PT Rineka Cipta

Ahmadi, Khoiru dan Amri, Sofan. 2014. Pengembangan dan Model Pembelajaran Tematik Integratif. Jakarta: PT Prestasi Pustakaraya

Al-Tabany. T. I. B. 2014. Mendesain Model Pembelajaran Inovatif, Progresif, dan Kontekstual. Jakarta : Prenadamedia Group

Arikunto, Suharsimi. 2016. Dasar- Dasar Evaluasi Pendidikan. Jakarta: Bumi Aksara

2014. Prosedur Penelitian Suatu Pendekatan Praktik. Jakarta: Rineka Cipta 
Aulia, Nur. 2016. Perbedaan Hasil Belajar Siswa Yang Diajar Dengan Strategi Pembelajaran Kooperatif Tipe Tink-Pair Share (TPS)Dan Strategi Pembelajaran Teams Games Turnament (TGT) Pada Materi Kubus Dan Balok Di Kelas VIII MTS Darul Ilmi Batang Kuis Area 2015/2016. Skripsi

Ayuningrum, Retna. 2016. Eksperimentasi Model Pembelajaran Kooperatif Tipe Teams Games Tournament (TGT) Dan Think Pair Share (TPS) Pada Materi Aljabar Ditinjau Dari Kecerdasan Logis Matematis Siswa Kelas VII SMP Negeri Se-Kota Surakarta Tahun Pelajaran 2015/2016. Jurnal Elektronik Pembelajaran Matematika. Vol. 4 No. 5 Hal. 549- 462

Basri, Hasan. 2015. Paradigma Baru Sistem Pembelajaran. Bandung: CV Pustaka Setia

Fathurrohman, Muhammad. 2015. model- model pembelajaran inovatif. Jogjakarta: Ar- ruzz media

Hadi, Sutrisno. 2015. Metodologi Riset. Yogyakarta: Pustaka Belajar Offset

Istarani. 2017. Lima Puluh Delapan Model Pembelajaran Inovatif. Medan: Media Persada

Jihat, Asep dan Haris, Abdul. 2012. Evaluasi Pembelajaran. Jogjakarta: Multipressind. 2015.

Khairani, Makmun. 2013. Psikologi Belajar. Jogjakarta: Aswaja Pressindo

Kurniasih, Imas dan Sani, Berlin. 2015. Ragam Pengembangan Model Pembelajaran. Jogjakarta: Kata Pena

Kurniawan, Deni. 2014. Pembelajaran Terpadu Tematik. Bandung: Alfabeta

Majid, Abdul. 2017. Pembelajaran Tematik Terpadu. Bandung: PT Remaja

Rosdakarya

Mukhadimah, D.A. 2015. Komparasi Metode Team Group Tournament (TGT) Dan Metode Think Pair Share (TPS) Terhadap Hasil Belajar Sosiologi Siswa Kelas XI IPS SMA. Skripsi

Purwanto. 2017. Evaluasi Hasil Belajar. Yogjakarta: PT Pustaka Pelajar

Rusman. 2012. Model- Model Pembelajaran.Jakarta: PT Raja Grafindo Persada

Shoimin, Aris. 2016. Enam Puluh Delapan Model Pembelajaran Inovatif dalam Kurikulum 2013. Yogyakarta: Ar- Ruzz Media

Sudjana. 2016. Penilaian Hasil Proses Belajar Mengajar. Bandung: PT Remaja Rosdakarya 
Sumanto. 2014. Statistika Terapan, Yogyakarta: PT Buku Seru

Susanto, Ahmad. 2015. Teori Belajar dan Pembelajaran di Sekolah Dasar. Jakarta: Prenadamedia Group.

Sugiyono. 2016. Cara Mudah Menyusun Skripsi, Tesis, dan Disertasi. Bandung: Alfabeta.

. 2017a. Metode Penelitian Kuantitatif, kualitatif, dan R\&D. Bandung:

Alfabeta

. 2017b. Metode Penelitian Kuantitatif, kualitatif, dan R\&D. Bandung:

Alfabeta

Trianto. 2018. Mendesain Model Pembelajaran Inovatif- Progresif. Jakarta: Kencana Prenada Media Group 